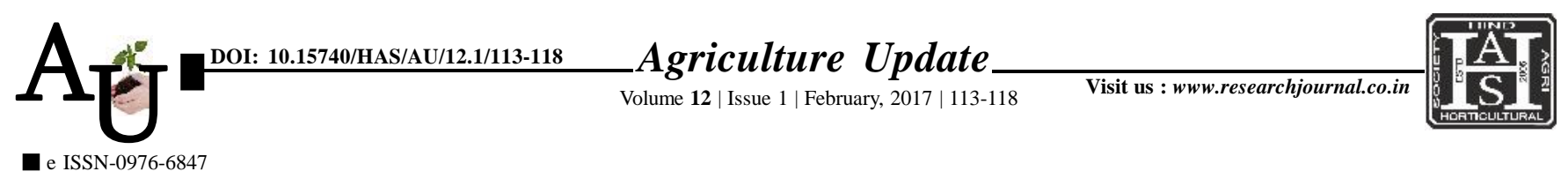

\title{
Rевевсн автіск: A study of self-help groups in Konkan and western Maharashtra
}

\begin{tabular}{l} 
Article Chronicle: \\
\hline Received : \\
01.12.2016; \\
Revised : \\
05.01.2017; \\
Accepted : \\
12.01.2017
\end{tabular}

KeY Words: Activities, Self-help groups

Author for correspondence :

RADHIKA BHONGALE Department of

Extension Education, College of Agriculture, Dr. Balasaheb Sawant Konkan Krishi Vidyapeeth, Dapoli, RATNAGIRI (M.S.) INDIA Email:radhika5101990 @ gmail.com

See end of the article for authors' affiliations
SUMMARY : The present study was conducted in Dapoli and Guhagar tahsils of Ratnagiri district (Konkan region) and Baramati and Indapur tahsils of Pune district (Western region) of Maharashtra. The sample constituted of 120 SHGs heads from 12 villages. The respondents were interviewed with the help of specially designed schedule. Maximum number of the respondents belonged to the 'middle' age group, had education 'upto primary' level, pre-scheme annual income of 'Rs. 7,701 to 19,300/-', had '12' knowledge score, 'favourable' attitude towards SHG scheme, 'medium' social participation, 'medium' extension contact, 'medium' information seeking behaviour, received 'no institutional training' after participating in the SHGs and 'medium' market orientation. Activities undertaken by SHGs were vegetable cultivation (15.84 \%), retail shops ( $8.34 \%$ ), dairy (7.50\%), fish selling and Papad making (6.67\% each). This was followed by goat rearing, preparation of Masala and tailoring (5.00\% each), preparation of diwali stuffs $(4.17 \%)$, mess (3.34\%) and preparation of syrup, preparation of Shevai and snacks center ( $2.50 \%$ each). The other trades noticed were broom making, flour mill, paper bags making, pots making, vermi-compost making, Agarbatti making, dryfruits selling, preparation of aonla candy, preparation of decorative material and bag making (1.67\% each).

How to cite this article : Bhongale, Radhika, Hardikar, D.P. and Waghmode, Y.J. (2017). A study of self-help groups in Konkan and western Maharashtra. Agric. Update, 12(1): 113-118; DOI : 10.15740/HAS/AU/12.1/113118. 